\title{
PENERAPAN MODEL PEMBELAJARAN ARIAS UNTUK MENINGKATKAN AKTIVITAS DAN HASIL BELAJAR BIOLOGI PADA SISWA KELAS X IPA SEKOLAH MENENGAH ATAS IQRA' TERPADU KOTA BENGKULU
}

\author{
Endang Sulaiman ${ }^{1}$ dan Pariyanto ${ }^{2}$ \\ ${ }^{1,2}$ Pendidikan Biologi, Univeritas Muhammadiyah Bengkulu \\ Jl. Bali I Kecamatan Teluk Segara Kota Bengkulu Post 38211 \\ Email : ${ }^{1}$ endangsulaiman@umb.ac.id
}

\begin{abstract}
ABSTRAK
Penelitian ini bertujuan untuk meningkatkan aktivitas dan hasil belajar siswa dengan menggunakan penerapan model pembelajaran ARIAS. Penelitian ini telah dilakukan pada bulan September sampai Oktoebr 2019 di SMA Iqra Terpadu Kota Bengkulu pada kelas X IPA. Penelitian ini telah dilaksanakan dalam tiga siklus, dimana tiap siklus terdiri dari empat tahap yaitu: 1) Planning (rencana), 2) Action (tindakan), 3) Observation (observasi), 4) Reflection (refleksi). Pengumpulan data menggunakan tes di tiap akhir siklus dan lembar observasi. Data tes hasil belajar diperoleh dengan menggunakan ketuntasan belajar klasikal. Dari analisis hasil dan pembahasan diperoleh kesimpulan bahwa penerapan model pembelajaran ARIAS dapat meningkatkan aktivitas guru dan siswa dan hasil belajar Biologi. Pada siklus I diketahui dari lembar observasi aktivitas guru diperoleh nilai rata-rata 30,5 dengan kategori baik, siklus II dengan rata-rata 37,5 dengan kategori baik dan silkus III dengan rata-rata 41,5 dengan kategori baik. Pada lembar observasi siswa siklus I diperoleh nilai rata-rata 34,5 dengan kategori baik, siklus II dengan rata-rata 41,5 dengan kategori baik dan siklus III dengan rata-rata 41 dengan kategori baik. Dan hasil tes siswa mengalami peningkatan dimana pada siklus I diperoleh persentase ketuntasan belajar klasikal 56,25 \% dengan kriteria belum tuntas, siklus II diperoleh persentase ketuntasan belajar klasikal 78,12 \% dengan kriteria belum tuntas dan siklus III diperoleh persentase ketuntasan belajar klasikal 87,5 \% dengan kriteria tuntas.
\end{abstract}

Kata Kunci : ARIAS, Hasil belajar siswa, Model.

\section{PENDAHULUAN}

Dalam kegiatan suatu negara, pendidikan memegang peranan yang amat penting untuk menjamin kelangsungan hidup negara dan bangsa, karena pendidikan merupakan wahana untuk meningkatkan kualitas sumber daya manusia. Peningkatan kualitas sumber daya manusia tak lepas dari dunia pendidikan. Kegiatan pembelajaran lebih diarahkan pada pengalaman belajar langsung dari pada pengajaran (mengajar). Guru berperan sebagai fasilitator sehingga siswa lebih aktif berperan dalam proses belajar. Guru terbiasa memberikan peluang seluas-luasnya agar siswa dapat belajar lebih bermakna dengan memberi respon yang mengaktifkan semua siswa secara positif dan endukatif (Depdiknas, 2006: 5).

Hasil belajar dipengaruhi oleh berbagai faktor, baik faktor dari dalam (intern) maupun faktor dari luar (ekstern), yang termasuk faktor intern adalah faktor fisiologis dan psikologis misalnya kecerdasan motivasi, berprestasi dan kemampuan kognitif, sedangkan yang termasuk faktor ekstern adalah faktor keluarga, sekolah dan masyarakat, misalnya guru, kurikulum dan model pembelajaran (Slameto, 2003: 54-68).

Dalam kegiatan pembelajaran umumnya guru di SMA Iqra' Terpadu Kota Bengkulu masih banyak menggunakan metode ceramah, sehingga siswa kurang begitu aktif dalam belajar dan jarang dilibatkan langsung dalam pembelajaran. Dengan menerapkan model pembelajaran ARIAS siswa dituntut untuk lebih aktif dalam kegiatan belajar mengajar hal ini dikarenakan dalam langkah-langkah model pembelajaran ARIAS siswa diberi kesempatan untuk menerapkan pengetahuan yang baru mereka diperoleh selama pembelajaran dan siswa juga mendapat kesempatan untuk mengevaluasi teman dan diri siswa sendiri.

Berdasarkan hasil observasi di SMA Iqra' Terpadu Kota Bengkulu, di peroleh juga informasi bahwa hasil belajar biologi siswa kelas $\mathrm{X} \mathrm{IPA}_{1}$ belum mencapai ketuntasan belajar klasikal. Berdasarkan KKM sekolah yang harus di capai yakni memperoleh nilai 7,0 dengan presentase ketuntasan belajar klasikal $85 \%$ tanpa remedial. Oleh karena itu, perlu di adakan usaha perbaikan untuk meningkatkan kemampuan siswa salah satu caranya adalah dengan memperbaharui model pengajaran.

Didalam model pengajaran ARIAS ada lima kategori yang harus diperhatikan oleh guru dalam usaha menghasilkan pembelajaran yang menarik, bermakna dan memberikan tantangan bagi siswa. Kelima kategori tersebut adalah: (1) Assurance (Menanamkan rasa percaya diri), (2) Relevance (Berhubungan atau berkaitan), (3) Interest (Membangkitkan minat atau perhatian), (4) Assessment (Memberikan evaluasi atau penilaian), (5) Satisfaction (Memberikan penguatan atau penghargaan).

Pembelajaran ARIAS pernah diteliti oleh Rani Susilowati prodi fisika dimana pembelajaran model ARIAS ini mampu meningkatkan hasil belajar siswa berdasarkan data yang di dapat yaitu 
pelaksanaan tindakan sebanyak tiga siklus dimana siklus satu sampai siklus tiga belajarnya $75,26 \%$, pada siklus dua ketuntasan belajarnya naik menjadi $75,30 \%$ dan pada siklus tiga ketuntasan belajarnya naiknya pun naik mencapai target $88,17 \%$, dan model pembelajaran ARIAS ini belum pernah diterapkan di Biologi.

Model pembelajaran ARIAS ini adalah salah satu cara yang dapat di coba sebagai suatu alternatif dari sekian banyak model pembelajaran dalam usaha meningkatkan aktivitas dan hasil

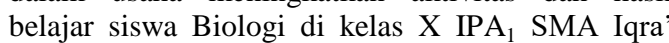
Terpadu Kota Bengkulu. Walaupun penelitian serupa mengenai model pembelajaaran Arias sudah banyak dilakukan sebelumnya, namun penelitian mengenai Penerapan Model Pembelajaran ARIAS Untuk Meningkatkan Aktivitas dan Hasil Belajar Biologi Pada Siswa Kelas X IPA ${ }_{1}$ SMA Iqra' Terpadu Kota Bengkulu dirasa sangat perlu untuk dilakukan.

\section{METODOLOGI PENELITIAN}

Berdasarkan latar belakang dan rumusan masalah yang dikemukakan, maka jenis penelitian ini merupakan penelitian tindakan kelas (PTK). Wardani dkk (2005:4) penelitian tindakan kelas adalah penelitian yang dilakukan oleh guru di dalam kelasnya sendiri melalui refleksi diri dengan tujuan untuk memperbaiki kinerjanya sebagai guru, sehingga hasil belajar siswa menjadi meningkat. Penelitian di laksanakan pada bulan September

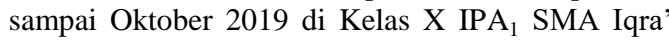
Terpadu Kota Bengkulu. Sedangkan Subjek penelitian tindakan kelas ini adalah seluruh siswa kelas X IPA SMA 1 Iqra' Terpadu Kota Bengkulu dengan jumlah siswa 32 orang. Penelitian yang di laksanakan adalah penelitian tindakan kelas (PTK) dalam tindakan siklus. Setiap siklus terdiri dari 4 tahap yaitu : 1) Perencanaan (Planning), 2) Tindakan (Action), 3) Observasi (Observation), 4) Refleksi (Reflection).

Tahap-tahap yang dilakukan dalam

prosedur penelitian ini adalah :

1. Tahap Perencanaan (Planning)

Pada tahap perencanaan kegiatan ini disusun rencana yang akan dilakukan dalam penerapan model pembelajaran ARIAS :

a. Membuat silabus pembelajaran materi pokok bahasan ciri-ciri virus

b. Membuat rencana pelaksanaan pembelajaran (RPP) pada pokok bahasan ciri-ciri virus

c. Membuat lembar diskusi siswa (LDS)

d. Membuat lembar observasi aktivitas guru dan lembar obseravasi aktivitas siswa

e. Mendesain alat evaluasi berupa soal tes esay

2. Tindakan (Action)

Pada penerapan model pembelajaran ARIAS

yang akan dilakukan adalah:

a. Guru mengkondisikan siswa dalam keadaan siap belajar

b. Guru memastikan bahwa setiap siswa mempunyai buku pegangan c. Guru menjelaskan prosedur penerapan model pembelajaran ARIAS dan melaksanakan pembelajaran

\section{Observasi (Observation)}

Lembar observasi guru digunakan untuk mengetahui kekurangan-kekurangan yang dilakukan oleh guru pada saat mengajar sedangkan lembar observasi siswa digunakan untuk mengetahui keaktifan siswa selama proses belajar mengajar berlangsung.

\section{Refleksi (Reflection)}

Pada tahap refleksi ini dilakukan evaluasi hasil observasi maupun hasil tes yang dilakukan pada tindakan I, dari hasil refleksi dapat dilihat faktor-faktor yang menghambat pada proses belajar mengajar agar dapat diperbaiki pada tindakan berikutnya.

Sedangkan Instrumen penelitian ini adalah : a) Instrument non tes terdiri dari lembar observasi guru dan siswa dan b) Instrument tes berupa hasil belajar yang dilakukan pada akhir siklus. Tes digunakan untuk mengetahui hasil belajar siswa tentang materi yang baru saja diajarkan.

Teknik Pengumpulan data : a) Wawancara : Wawancara dilkukan sebelum penelitian untuk mengetahui kondisi maupun kendala-kendala dalam proses pembelajaran biologi. Gambaran-gambaran ini dapat dijadikan landasan dalam pelaksanaan penelitian. b). Observasi : Observasi adalah model atau cara-cara menganalisis dan mengadakan pencatatan secara sistematis mengenai tingkah laku dengan melihat atau mengamati individu atau kelompok secara langsung (Purwanto, 2004 : 149). Lembar observasi siswa digunakan untuk melihat keaktifan siswa selama proses pembelajaran berlangsung, sedangkan lembar observasi guru untuk mengamati aktivitas guru dalam proses belajar (Zuriah, 2007 : 174). Penataan data dilakukan dengan mempergunakan sebuah daftar yang memuat nama observer disertai jenis gejala yang diamati. Tugas observer memberi tanda cek $(\sqrt{ })$ pada gejala yang muncul.

Tes Hasil Belajar :Tes hasil belajar adalah tes yang dipergunakan untuk menilai hasil-hasil pelajaran yang telah diberikan oleh guru kepada murid-muridnya, atau oleh dosen kepada mahasiswa, dalam jangka waktu tertentu (Purwanto, 2004 : 33).

G. Tehnik Analisis Data

\section{Menganalisis Data Observasi}

Data hasil observasi menggunakan lembar observasi guru dan lembar observasi siswa untuk setiap aspek yang di amati di olah dengan ketentuan sebagai berikut:

a. Rata-rata skor $=$ jumlah skor jumlah observasi

b. Skor tertinggi $=$ jumlah butir observasi $\mathrm{x}$ skor tertinggi tiap butir

c. Kisaran nilai untuk setiap pengamatan $=$ skor tertinggi keseluruhanskor tertinggi tiap butir (Sudjana, 2001 : 132-133)

2. Lembar Observasi Aktivitas Guru dan Siswa 
Lembar observasi guru yang digunakan pada saat proses pembelajaran (pelaksanaan tindakan) bertujuan untuk mengetahui kekurangankekurangan yang dilakukan guru pada saat mengajar. Sedangkan lembar observasi siswa digunakan untuk mengetahui keaktifan siswa selama proses belajar mengajar berlangsung. Hasil dari observasi ini akan dijadikan pedoman dalam memperbaiki proses belajar mengajar pada siklus berikutnya.

Pada lembar observasi aktivitas guru dan siswa, jumlah butir observasi adalah 16 butir. Skor tertinggi adalah 3 dan skor terendahnya adalah 1 . Kisaran nilai untuk kriteria pengamatan adalah :

$\underline{\text { Skor tertinggi keseluruhan }}-\underline{48}=16$

Skor tertinggi tiapbutir observasi 3

Nilai tiap kriteria pengamatan aktivitas guru dan siswa

\begin{tabular}{lll}
\hline \multicolumn{1}{c}{ No } & \multicolumn{1}{c}{ Interval Nilai } & \multicolumn{1}{c}{ Kriteria } \\
\hline 1. & $1-16$ & Kurang \\
\hline 2. & $17-32$ & Cukup \\
\hline 3. & $33-48$ & Baik \\
\hline
\end{tabular}

Skor tiap butir pengamatan adalah :

\begin{tabular}{lll}
\hline \multicolumn{1}{c}{ No } & Skor & \multicolumn{1}{c}{ Kriteria } \\
\hline 1. & 3 & Baik \\
\hline 2. & 2 & Cukup \\
\hline 3. & 1 & Kurang \\
\hline
\end{tabular}

(Sudjana, $2001:$ 77-78)

\section{Menganalisis data tes hasil belajar tiap siklus}

Penilaian hasil belajar siswa untuk setiap siklus yang berupa nilai tes yang akan di analisa dengan ketentuan sebagai berikut :

\section{Ketuntasan belajar klasikal}

$\mathrm{KB}=\underline{\mathrm{Ns}} \times 100 \%$ SMA IT Kota Bengkulu, 2018) Keterangan :

$$
\mathrm{KB}=\text { Ketuntasan belajar }
$$

Ns = Jumlah siswa yang mendapatkan nilai $\geq 7,0$ nilai KKM.

$\mathrm{S}=$ Jumlah siswa

Suatu kelas dikatakan telah tuntas belajar, apabila di kelas tersebut terdapat $85 \%$ siswa yang mendapat nilai $\geq 7,0$.

\section{HASIL PENELITIAN}

Berdasarkan penelitian yang dilakukan dalam III siklus dengan menerapkan model pembelajaran ARIAS untuk meningkatkan aktivitas dan hasil belajar Biologi pada siswa Kelas X IPA SMA Iqra Terpadu Kota Bengkulu, diperoleh hasil sebagai berikut:

\section{Siklus I}

Siklus ini terdiri dari rencana tindakan I, pelaksanaan tindakan I, observasi I dan refleksi I A. Rencana Tindakan I

Pada tahap ini peneliti menyusun perangkat mengajar dengan menerapkan model pembelajaran ARIAS yaitu: Membuat silabus pembelajaran materi tentang pokok bahasan ciri-ciri virus, membuat RPP siklus I, membuat LDS siklus I, membuat lembar observasi aktivitas guru dan siswa, membuat soal tes akhir siklus I.

B. Pelaksanaan Tindakan I

Pelaksanaan tindakan siklus I ini dilaksanakan pada hari senin tanggal 9 September 2019 dengan alokasi waktu ( 2 x 40 menit) di kelas X $\mathrm{IPA}_{1}$ SMA Iqra' Terpadu Kota Bengkulu dengan jumlah siswa 32 orang siswi perempuan. Pada pertemuan ini peneliti sebagai guru menerapkan model pembelajaran ARIAS dalam proses belajar mengajar berlangsung dengan pokok bahasan ciriciri virus. Guru memotivasi siswa dengan bertanya, apakah virus dapat dikategorikan sebagai makhluk hidup? Guru menjelaskan cara belajar dengan menerapkan model pembelajaran ARIAS. Guru membagi siswa menjadi 8 kelompok yang masingmasing beranggotakan 4 orang, guru menyampaikan tujuan pembelajaran kepada siswa dan guru menjelaskan materi pokok bahasan yang akan dipelajari secara garis besar. Guru mengajukan pertanyaan/permasalahan yang berkaitan dengan pelajaran kepada siswa dalam bentuk diskusi siswa (LDS) yang harus diselesaikan setiap kelompok, guru mendatangi setiap kelompok untuk mengamati kegiatan siswa dan membantu siswa untuk mengisi LDS tahap demi tahap. Guru memberikan kesempatan kepada setiap kelompok untuk mempersentasikan hasil diskusinya, guru meminta tanggapan dari kelompok lain, guru memberikan jawaban yang benar tentang permasalahan atau pertanyaan yang ada dalam LDS tersebut, guru memberikan kesempatan kepada siswa untuk membantu temannya yang mengalami kesulitan. Guru memberikan penghargaan pada kelompok yang hasil diskusinya baik, guru membimbing siswa untuk siswa untuk menarik kesimpulan dari materi yang baru saja diajarkan.

Setelah proses pembelajaran pada siklus I selesai, kemudian guru mengadakan tes individual. Tes ini dimaksudkan untuk mengetahui sejauh mana materi ciri-ciri virus telah dikuasai dan bagaimana hasil siswa dengan menggunakan penerapan model pembelajaran ARIAS.

C. Observasi (Observation)

Dalam tahap ini observasi terhadap pelaksanaan tindakan model pembelajaran ARIAS. Observasi ini dilakukan terhadap guru dan siswa yang dengan menggunakan lembar observasi. Lembar observasi guru digunakan untuk mengetahui kekurangan-kekurangan yang dilakukan oleh guru pada saat mengajar sedangkan lembar observasi siswa digunakan untuk mengetahui keaktifan siswa selama proses belajar mengajar berlangsung. Hasil dari observasi ini akan dijadikan pedoman dalam memperbaiki proses belajar mengajar pada siklus berikutnya.

\section{1). Hasil Observasi Terhadap Aktivitas Guru}

Dari observasi yang telah dilakukan oleh dua orang observer diperoleh total skor 67 dengan rata-rata 30,5 termasuk ke dalam kriteria baik seperti terlihat dalam tabel.2 
Tabel 2. Data Hasil Observasi Terhadap Aktivitas Guru Siklus I

\begin{tabular}{|c|c|c|c|c|}
\hline Observer & Skor & $\begin{array}{l}\text { Total } \\
\text { Skor }\end{array}$ & $\begin{array}{l}\text { Rata- } \\
\text { rata } \\
\text { Skor } \\
\end{array}$ & Kriteria \\
\hline 1 & 29 & 61 & 30,5 & Cukup \\
\hline 2 & 32 & & & \\
\hline
\end{tabular}

Berdasarkan table.2 di atas, dapat diketahui bahwa aktivitas guru selama mengajar secara keseluruhan sudah termasuk dalam kategori cukup. Namun pada lembar observasi yang diisi oleh observer, masih terdapat beberapa aspek yang kurang begitu terlaksana dengan baik. Adapun aspek-aspek tersebut antara lain:

- Guru masih kurang memberikan pertanyaan prasyarat dan motivasi

- Guru kurang membimbing dan meminta siswa untuk berdiskusi

- $\quad$ Guru kurang memberi kesempatan kepada siswa untuk mengadakan evaluasi terhadap teman dan dirinya sendiri

2). Hasil Observasi Terhadap Aktivitas Siswa

Aktivitas siswa selama proses

pembelajaran dapat dilihat pada tabel.3

Tabel 3. Data Hasil Observasi Terhadap

Aktivitas Siswa Siklus I

\begin{tabular}{lllll}
\hline Observer & Skor & $\begin{array}{l}\text { Total } \\
\text { Skor }\end{array}$ & $\begin{array}{l}\text { Rata- } \\
\text { rata } \\
\text { Skor }\end{array}$ & Kriteria \\
\hline 1 & 34 & 69 & 34,5 & Baik \\
2 & 35 & & & \\
\hline
\end{tabular}

Dari tabel.3 di atas dapat dilihat secara keseluruhan aktivitas siswa dalam belajar sudah termasuk dalam kategori baik. Namun pada lembar observasi yang diisi oleh observer masih terdapat beberapa aspek yang kurang begitu terlaksana dengan baik, aspek-aspek tersebut adalah:

- Siswa masih kurang menjawab pertanyaan prasyarat dan pertanyaan motivasi yang di berikan oleh guru

- Masih banyak siswa yang belum mengadakan evaluasi terhadap teman dan dirinya sendiri

\section{b. Refleksi}

Setelah pelaksanaan proses belajar mengajar pada penerapan model pembelajaran ARIAS dan dilakukan pengamatan serta evaluasi ternyata hasil belajar siswa belum mencapai target yang diinginkan. Oleh karena itu masih banyak kekurangan yang perlu diperbaiki, mengingat dalam proses belajar mengajar selalu ada kelemahan dan kekurangan.

Adapun kelemahan-kelemahan pada siklus I dengan menerapkan model pembelajaran ARIAS yaitu: Pada komponen assurance ini siswa belum aktif dalam menjawab pertanyaan prasyarat dan motivasi yang diberikan guru. Dalam tahap ini siswa juga belum memiliki rasa percaya diri untuk mengeluarkan ide dalam merumuskan masalah. Pada interest ini guru masih kurang memberikan perhatian kepada siswa sebelum melaksanakan diskusi kelompok sehingga siswa masih banyak yang ribut dan memilih diam dalam kelompoknya, guru kurang memberi kesempatan kepada kelompok lain untuk menanggapi sewaktu ada kelompok yang sedang memprensentasikan hasil diskusinya dan siswa kurang menanggapi presentasi dari kelompok lain. Tahap satisfaction guru kurang memberi penguatan/penghargaan kepada siswa dan guru kurang memberi kesempatan kepada siswa untuk membantu temannya yang mengalami kesulitan. Untuk itu perlu adanya perbaikan agar proses belajar mengajar yang dilaksanakan berjalan dengan baik dan memperoleh hasil yang diinginkan. Adapun halhal yang perlu diperbaiki pada penerapan model pembelajaran ARIAS pada siklus I yaitu:

a. Guru hendaknya menanamkan rasa percaya diri dalam diri siswa untuk mengeluarkan ide dalam merumuskan masalah dan dalam menjawab pertanyaan prasyarat yang diberikan guru.

b. Guru hendaknya membimbing dan meminta siswa untuk berdiskusi

c. Guru hendaknya memberikan kesempatan kepada seluruh siswa untuk mengadakan evaluasi terhadap teman dan terhadap diri sendiri. Sehingga siswa menjadi aktif dalam belajar.

\section{c. Deskripsi nilai tes siklus I}

Tes diberikan dalam bentuk tes tertulis yang dilaksanakan setelah proses pembelajaran berlangsung. Tes berisikan soal-soal esay yang dibuat berdasarkan indikator yang ingin dicapai setiap selesai mempelajari materi, soal-soal dapat dilihat pada lampiran 3, 8 dan 13 .

Berdasarkan hasil tes yang kemudian dianalisis dengan kriteria persentase ketuntasan belajar klasikal siswa, maka diperoleh hasil seperti terlihat pada tabel.4 dibawah ini.

Tabel 4. Persentase Ketuntasan Belajar Klasikal Siswa Siklus I

\begin{tabular}{ccc|}
\hline $\begin{array}{c}\text { Jumlah siswa yang mendapatkan } \\
\text { nilai } 70 \text { ke atas }\end{array}$ & $\begin{array}{c}\text { Persentasi ketuntasan belajar } \\
\text { klasikal }\end{array}$ & Kriteria ketuntasan belajar klasikal \\
\hline 18 Orang & $56,25 \%$ & Tidak Tuntas \\
\hline
\end{tabular}

Tabel.4 di atas menunjukan bahwa siswa yang mendapat nilai 7,0 ke atas hanya 18 orang dari 32 siswa. Setelah di analisis dengan kriteria ketuntasan belajar klasikal maka di dapat persentase ketuntasan belajar sebesar 56,25\%, ini berarti bahwa pembelajaran yang telah dilaksanakan pada siklus I belum mencapai ketuntasan belajar klasikal.

Sebab menurut KKM SMA Iqra' Terpadu Kota Bengkulu (2018/2019), ketuntasan belajar klasikal dicapai apabila $85 \%$ dari jumlah siswa mendapat nilai 7,0 ke atas.

Belum tuntasnya proses pembelajaran pada siklus I disebabkan oleh proses pembelajaran Biologi dengan menerapkan model pembelajaran 
ARIAS ini masih belum terlaksana secara optimal, hal ini ditandai dengan adanya aspek yang kurang selama proses pembelajaran baik pada aktivitas guru maupun pada aktivitas siswanya.

\section{Siklus II}

\section{A. Rencana Tindakan II}

Pada tahap ini peneliti menyusun kembali perangkat mengajar dengan menerapkan model pembelajaran ARIAS seperti yang dilakukan pada perencanaan tindakan I.

\section{B. Pelaksanaan tindakan II}

Pelaksanaan tindakan ini dilaksanakan pada hari Senin tanggal 9 September 2019 dengan alokasi waktu ( 2 x 40 menit) di kelas X IPA SMA Iqra' Terpadu Kota Bengkulu dengan jumlah siswa 32 orang yaitu siswa perempuan.

C. Observasi (Observation)

Dalam tahap ini dilaksanakan observasi terhadap aktivitas guru dan keaktifan siswa dalam penerapan model pembelajaran ARIAS yang dilakukan terhadap peneliti dan siswa dengan menggunakan lembar observasi yang dilakukan oleh dua orang observer.

\section{1). Hasil Observasi Terhadap Aktivitas Guru} pada tabel.5

Aktivitas guru pada siklus II dapat dilihat

Tabel 5. Data Hasil Observasi Terhadap Aktivitas Guru Siklus II

\begin{tabular}{|c|c|c|c|c|}
\hline Observer & Skor & $\begin{array}{l}\text { Total } \\
\text { Skor }\end{array}$ & $\begin{array}{c}\text { Rata-rata } \\
\text { Skor }\end{array}$ & Kriteria \\
\hline 1 & 38 & 75 & 37,5 & Baik \\
\hline 2 & 37 & & & \\
\hline
\end{tabular}

Total skor yang didapat dari hasil observasi terhadap aktivitas guru yang dilakukan oleh dua observer pada siklus II yaitu 75 dengan rata-rata skor 37,5 rata-rata skor tersebut dalam kriteria baik, tetapi masih terdapat kelemahan-kelemahan yaitu:

- Guru diharapkan menjelaskan tujuan pembelajaran dengan jelas dan menggunakan bahasa yang jelas sehingga siswa lebih mudah memahami materi pelajaran

- Guru masih kurang membimbing dan membagi perhatian kepada setiap kelompok secara merata

\section{2). Hasil Observasi Terhadap Aktivitas Siswa}

Data hasil aktivitas siswa selama proses pembelajaran dapat dilihat pada table. 6

Tabel 6. Data Hasil Observasi Terhadap Aktivitas Siswa Siklus II

\begin{tabular}{ccccc}
\hline Observer & Skor & $\begin{array}{c}\text { Total } \\
\text { Skor }\end{array}$ & $\begin{array}{c}\text { Rata- } \\
\text { rata } \\
\text { Skor }\end{array}$ & Kriteria \\
\hline 1 & 41 & 82 & 41 & Baik \\
2 & 41 & & & \\
\hline
\end{tabular}

Dari tabel.6 diatas terlihat secara keseluruhan aktivitas siswa dalam belajar sudah termasuk kedalam kategori baik. Namun pada lembar observasi yang diisi oleh observer masih terdapat beberapa aspek yang kurang begitu terlaksana dengan baik, aspek-aspek tersebut adalah:

- Sebagian siswa sudah bisa menjawab pertanyaan prasayarat dan motivasi

Masih ada beberapa siswa yang belum mencatat tujuan pembelajaran dan memperhatikan penjelasan guru didepan kelas a. Deskripsi nilai tes siklus II

Berdasarkan hasil tes yang kemudian dianalisis dengan kriteria persentase ketuntasan belajar klasikal siswa, maka diperoleh hasil seperti terlihat pada tabel.7 dibawah ini.

Tabel 7. Persentase Ketuntasan Belajar Klasikal Siklus II

\begin{tabular}{ccc}
\hline $\begin{array}{c}\text { Jumlah Siswa yang Mendapat Nilai } 70 \\
\text { Ke atas }\end{array}$ & $\begin{array}{c}\text { Persentase Ketuntasan } \\
\text { Belajar Klasikal }\end{array}$ & $\begin{array}{c}\text { Kriteria Ketuntasan Belajar } \\
\text { Klasikal }\end{array}$ \\
\hline 25 Orang & $78,12 \%$ & Belum Tuntas
\end{tabular}

Tabel.7 di atas menunjukan bahwa siswa yang mendapat nilai 7,0 ke atas hanya 25 orang dari 32 siswa. Setelah di analisis dengan kriteria ketuntasan belajar klasikal maka di dapat persentase ketuntasan belajar sebesar 78,12 \%, ini berarti bahwa pembelajaran yang telah dilaksanakan pada siklus I belum mencapai ketuntasan belajar klasikal. Karena menurut KKM SMA Iqra' Terpadu Kota Bengkulu (2018/2019), ketuntasan belajar klasikal dicapai apabila $85 \%$ dari jumlah siswa mendapat nilai 7,0 ke atas.

\section{c. Refleksi}

Kegiatan belajar mengajar pada siklus II sudah cukup baik dibandingkan siklus I, artinya ada peningkatan aktivitas guru dan aktivitas siswa serta hasil belajar. Akan tetapi pada siklus ini masih ada kelemahan dan kekurangan yaitu: Pada komponen assurance ini sebagian siswa sudah mulai aktif dalam menjawab pertanyaan prasyarat yang diberikan oleh guru, pada komponen relevance ini sebagian siswa sudah menyimak dan memperhatikan penjelasan guru mengenai tujuan pembelajaran. Untuk mengatasi aspek-aspek yang masih kurang pada siklus II, maka perlu langkah-langkah perbaikan yang dilaksanakan pada silkus II yaitu:

a. Guru harus menanamkan rasa percaya diri dalam diri siswa untuk mengeluarkan ide dan merumuskan masalah.

b. Guru hendaknya menarik minat/perhatian siswa dalam belajar sehingga aktif dalam diskusi.

\section{Siklus III}

A. Rencana Tindakan III

Pada tahap ini peneliti menyusun kembali perangkat mengajar dengan menerapkan model pembelajaran ARIAS yaitu: Membuat RPP siklus III dengan pokok bahasan ciri-ciri makhluk hidup, 
membuat LDS siklus III, membuat lembar observasi aktivitas guru dan siswa, membuat soal tes akhir siklus III.

\section{B. Pelaksanaan Tindakan III}

Pelaksanaan tindakan siklus III ini dilaksanakan pada hari Senin 16 September 2019 dengan alokasi waktu ( 2 x 40 menit) di kelas X IPA SMA Iqra' Terpadu Kota Bengkulu dengan jumlah siswa 32 orang yaitu siswa perempuan. Pada pertemuan ketiga ini guru menerapkan model pembelajaran ARIAS dalam proses belajar mengajar berlangsung dengan pokok bahasan ciri-ciri virus

\section{Observasi (Observation)}

Dalam tahap lembar observasi digunakan untuk mengetahui peran guru dan kegiatan siswa dalam proses belajar mengajar sebagai umpan balik dalam melaksanakan proses belajar mengajar.

\section{a). Hasil Observasi Terhadap Aktivitas Guru}

Pada tindakan III dilakukan perbaikan terhadap kekurangan-kekurangan yang terjadi pada tindakan II, dari observasi yang dilakukan oleh dua orang pengamat terhadap proses pembelajaran yang dilakukan, data observasi di analisis kemudian diperoleh skor seperti pada table. 8 di bawah ini:

Tabel 8. Data Hasil Observasi Terhadap

Aktivitas Guru Siklus III

\begin{tabular}{ccccc}
\hline Observer & Skor & $\begin{array}{c}\text { Total } \\
\text { Skor }\end{array}$ & $\begin{array}{c}\text { Rata- } \\
\text { rata } \\
\text { Skor }\end{array}$ & Kriteria \\
\hline 1 & 42 & 83 & 41,5 & Baik \\
2 & 41 & & & \\
\hline
\end{tabular}

Dari data observasi yang dilakukan oleh pengamat diperoleh total skor 83 dengan rata-rata skor 41,5 tersebut sudah termasuk kedalam kategori baik. Berdasarkan pengamatan yang dilakukan selama proses pembelajaran pada siklus III aktivitas guru dalam siklus sudah sangat baik. Pada siklus ini sudah dilakukan perbaikan-perbaikan dari kelemahan-kelemahan pada siklus sebelumnya.

b). Hasil Observasi Terhadap Aktivitas Siswa

Data hasil aktivitas siswa selama proses pembelajaran dapat dilihat pada tabel.9.

Tabel 9. Data Hasil Observasi Terhadap Aktivitas Siswa Siklus III

\begin{tabular}{ccccc}
\hline Observer & Skor & $\begin{array}{c}\text { Total } \\
\text { Skor }\end{array}$ & $\begin{array}{c}\text { Rata- } \\
\text { rata } \\
\text { Skor }\end{array}$ & $\begin{array}{c}\text { Kriteri } \\
\text { a }\end{array}$ \\
\hline 1 & 41 & 82 & 41 & Baik \\
2 & 41 & & & \\
\hline
\end{tabular}

Dari data observasi yang dilakukan oleh kedua pengamat diperoleh skor rata-rata 41 , secara keseluruhan aktivitas dalam penerapan pembelajaran model ARIAS sudah termasuk kedalam kategori baik yaitu masih ada beberapa orang siswa yang memilih diam untuk tidak berpartisipasi dalam mengeluarkan ide pada tahap-tahap penyajian.

Berdsarkan hasil tes yang kemudian dianalisa dengan kriteria ketuntasan belajar klasikal maka diperoleh hasil pada table.10 di bawah ini

Tabel 10. Persentase Ketuntasan Belajar Klasikal Siklus III

\begin{tabular}{ccc}
\hline $\begin{array}{c}\text { Jumlah Siswa yang Mendapat Nilai } 70 \\
\text { Ke atas }\end{array}$ & $\begin{array}{c}\text { Persentase Ketuntasan } \\
\text { Belajar Klasikal }\end{array}$ & $\begin{array}{c}\text { Kriteria Ketuntasan Belajar } \\
\text { Klasikal }\end{array}$ \\
\hline 28 Orang & $87,5 \%$ & Tuntas
\end{tabular}

Dilihat dari tabel di atas, 28 orang siswa dari 32 siswa mendapat niali 7,0 ke atas dengan persentase ketuntasan belajar sebesar 87,5\%. Persentase tersebut termasuk ke dalam kriteria tuntas karena menurut KKM SMA Iqra' Terpadu Kota Bengkulu (2018/2019), menyatakan bahwa ketuntasan belajar klasikal dicapai apabila $85 \%$ dari jumlah siswa mendapat nilai 7,0 ke atas, walaupun masih ada siswa yang belum tuntas belajarnya.

\section{(3). Refleksi}

Berdasarkan hasil pengamatan aktivitas guru dan siswa serta hasil evaluasi selama proses pembelajaran dengan menerapkan model pembelajaran ARIAS sudah menampakkan hasil yang optimal. Hal ini dapat dilihat dari semua aspek pengamatan aktivitas guru dan siswa serta hasil belajar.

Guru sudah mampu menanamkan rasa percaya diri pada diri siswa untuk mengeluarkan ide dalam merumuskan masalah, menyampaikan manfaat pelajaran, menarik minat/perhatian siswa untuk aktif dalam diskusi, memberikan kesempatan kepada siswa untuk mengevaluasi dirinya sendiri, mengevaluasi temannya dan membantu teman mereka yang mengalami kesulitan dalam belajar.

Berdasarkan hasil penelitian yang telah dilakukan dengan menerapkan model pembelajaran ARIAS (Assurance, relevance, interest, assessment dan satisfaction) dalam III siklus yang telah dilaksanakan pada pokok bahasan ciri-ciri virus ternyata dapat meningkatkan hasil belajar siswa kelas X IPA 1 SMA Iqra' Terpadu Kota Bengkulu.

\section{Peningkatan Aktivitas}

Peningkatan hasil belajar siswa tidak terlepas dari keaktifan guru dan siswa dalam proses belajar mengajar. Dalam kegiatan belajar mengajar pelaksanaan tindakan menunjukan adanya perbedaan antara aktivitas guru dan siswa. Hal ini dapat dilihat dari analisa lembar observasi guru dan siswa pada setiap siklus.

Pada siklus I proses pembelajaran dengan menerapkan model pembelajaran ARIAS termasuk kedalam kategori baik dilihat dari aktivitas guru dan dilihat dari aktivitas siswa juga baik. Dimana dari dua orang observer didapat nilai rata-rata aktivitas guru 30,5 (tabel.2) dan nilai rata-rata aktivitas siswa 34,5 (tabel.3). Namun, masih ada beberapa 
kelemahan yang harus diperbaiki pada siklus selanjutnya yaitu: a) guru masih kurang memberikan pertanyaan prasyarat dan memotivasi siswa, siswa belum memiliki rasa percaya diri untuk mengeluarkan ide dalam merumuskan masalah, b) guru kurang jelas dalam memberikan pengarahan kepada siswa sebelum melaksanakan diskusi kelompok.

Hal ini sejalan dengan pendapat Djamaah Sopah (2007) menyatakan bahwa seseorang yang memiliki sikap percaya diri tinggi cenderung akan berhasil bagaimanapun kemampuan yang ia miliki. Sikap dimana seseorang merasa yakin, percaya dapat berhasil mencapai sesuatu akan mempengaruhi mereka bertingkah laku untuk mencapai keberhasilan tersebut. Untuk mengembangkan pemahaman mengenai diri sendiri dan tanggung jawab, baik terhadap diri sendiri maupun terhadap kelompok (Hamalik, 2001).

Pada pelaksanaan siklus II terjadi peningkatan baik aktivitas guru dan aktivitas siswa dengan kriteria baik kelemahan yang terdapat pada siklus I sudah diperbaiki. Tetapi pada siklus II ini masih terdapat kelemahan pada penerapan model pembelajaran ARIAS yaitu dari kedua pengamat didapat nilai rata-rata skor observasi aktivitas guru 37,5 (tabel.5) dan rata-rata skor aktivitas siswa 41 (tabel.6), namun demikian pada siklus II ini masih ada kelemahan yang harus diperbaiki pada pertemuan selanjutnya. Peningkatan ini menunjukan bahwa pembelajaran dengan menerapkan model pembelajaran ARIAS dapat meningkatkan motivasi dan keaktifan siswa dalam kegiatan belajar mengajar serta meningkatkan prestasi siswa, dimana dalam kegiatan belajar mengajar siswa senantiasa termotivasi dan terlibat dalam proses pembelajaran dengan menerapkan model pembelajaran ARIAS yaitu siswa merasa kegiatan pembelajaran yang mereka ikuti memiliki nilai, bermanfaat dan berguna bagi kehidupan mereka. Siswa akan terdorong mempelajari sesuatu kalau apa yang akan dipelajarinya ada relevansinya dengan kehidupan mereka, dan memiliki tujuan yang jelas. Minat atau perhatian merupakan alat yang sangat berguna dalam usaha mempengaruhi hasil belajar siswa (Sopah, 2007).

Sedangkan pada siklus III semua aspek yang diamati sudah meningkat, hal ini disebabkan proses pembelajaran ARIAS sudah berlangsung secara optimal. Pada siklus III ini proses pembelajaran dengan menerapkan model pembelajaran ARIAS termasuk kedalam kategori baik, yaitu dari kedua pengamat didapat nilai ratarata skor guru dan siswa sama-sama 41 nilai mendekati nilai 42. Peningkatan ini menunjukan bahwa pembelajaran dengan menerapkan model pembelajaran ARIAS memberi pengaruh yang positif terhadap motivasi berprestasi dan hasil belajar siswa, siswa yang memiliki sikap percaya diri memiliki penilaian positif tentang dirinya cenderung menampilkan prestasi yang baik, sikap percaya diri yakin akan berhasil perlu ditanamkan kepada siswa untuk mendorong mereka agar berusaha dengan maksimal guna mencapai keberhasilan yang optimal (Sopah, 2007).

\section{Peningkatan Terhadap Hasil Belajar Siswa}

Penerapan model pembelajaran ARIAS ini adalah pembelajaran yang mendeskripsikan komponen untuk membangkitkan dan meningkatkan kegiatan pembelajaran yaitu dengan melibatkan lima komponen assurance (percaya diri), komponen relevance (berhubungan/ berkaitan), komponen interest (minat/perhatian), komponen assessment (evaluasi) dan komponen satisfaction (penghargaan) (Sopah, 2007).

Menurut Hamalik (2001) hasil belajar adalah bentuk perubahan tingkah laku, latihan dan pengembangan. Dalam hasil belajar Biologi, perubahan itu terjadi akibat perubahan ilmu pengetahuan, kebiasaan, keterampilan serta aspirasi dalam bentuk sikap dan nilai (Arikunto, 2002).

Berdasarkan data hasil penelitian sebelum dan sesudah tindakan dengan menerapkan model pembelajaran ARIAS pada sub pokok bahasan ciriciri virus. Jumlah siswa 32 orang di kelas X IPA dan semua siswa mengikuti tes pada siklus I dimana hasil tes siklus I tidak tuntas karena hanya 18 siswa yang sudah tuntas $56,25 \%$, sedangkan proses pembelajaran dikatakan tuntas apabila $85 \%$ dari jumlah siswa yang mendapat nilai 7,0 ke atas. Ketidaktuntasan pembelajaran pada siklus ini disebabkan masih kurang maksimalnya dalam penerapan model pembelajaran ARIAS sehingga masih ada beberapa kelemahan yang harus diperbaiki pada siklus ini, yang menyebabkan siswa masih belum mengerti serta kurang seriusnya siswa dalam mengikuti proses pembelajaran. Secara klasikal ketuntasan belajar siswa meningkat dari siklus I 18 orang, siklus II 25 orang dan siklus III 28 orang, tapi secara individual ada satu siswa yang hasil belajarnya tidak mengalami peningkatan tetapi mengalami penurunan, hal itu disebabkan adanya faktor-faktor yang mempengaruhi belajar seperti faktor intern (faktor yang ada dalam diri individual yang sedang belajar) dan faktor ekstren (faktor yang ada di luar individual) (Slameto, 2003: 54).

Pada siklus II dilaksanakan berdasarkan refleksi siklus I, artinya aspek-aspek yang sudah baik dipertahankan sedangkan yang masih kurang dilakukan perbaikan pada siklus II ini. Berdasarkan hasil tes (Lampiran 9) yang kemudian dianalisis dengan kriteria ketuntasan belajar klasikal siswa menunjukan bahwa siswa yang mendapat nilai 7,0 ke atas hanya 25 orang dari 32 siswa. Setelah dianalisis dengan kriteria ketuntasan belajar klasikal maka di dapat ketuntasan belajar sebesar 78,12 \%, ini berarti bahwa pembelajaran yang telah dilaksanakan pada siklus II belum mencapai ketuntasan belajar klasikal. Sebab menurut SMA Iqra' Terpadu Kota Bengkulu (2018/2019), ketuntasan belajar klasikal dicapai apabila $85 \%$ dari jumlah siswa mendapat nilai 7,0 ke atas.

Sedangkan pada siklus III ini merupakan kegiatan kelanjutan dan siklus terakhir dari kegiatan penelitian tindakan kelas yang di laksanakan. Proses pembelajaran dilakukan berdasarkan hasil dari 
refleksi tindakan II, di mana masih terdapat hal-hal yang belum dapat dilaksanakan dengan baik dalam menggunakan penerapan model pembelajaran ARIAS. Berdasarkan hasil tes (Lampiran 14) yang kemudian dianalisis denga kriteria ketuntasan belajar klasikal menunjukan bahwa 28 orang siswa dari 32 siswa mendapat nilai 7,0 ke atas dengan persentase ketuntasan belajar klasikal sebesar 87,5 \%. Persentase tersebut termasuk ke dalam kriteria tuntas karena menurut KKM SMA Iqra' Terpadu Kota Bengkulu (2018/2019), menyatakan bahwa ketuntasan belajar klasikal dicapai apabila $85 \%$ dari siswa mendapat nilai 7,0 ke atas, walaupun masih ada siswa yang belum tuntas belajarnya.

Evaluasi merupakan alat untuk mengetahui apakah yang telah diajarkan sudah dipahami oleh siswa, untuk memonitor kemajuan siswa sebagai individu maupun sebagai kelompok, untuk merekam apa yang telah siswa capai dan untuk membantu siswa dalam belajar. Bagi siswa evaluasi merupakan umpan balik tentang kelebihan dan kelemahan yang dimiliki, dapat mendorong belajar lebih baik dan meningkatkan motivasi berprestasi (Sopah, 2007).

\section{SIMPULAN}

Dari penerapan pembelajaran model ARIAS telah dilakukan terhadap mata pelajaran Biologi di SMA Iqra' Terpadu Kota Bengkulu pada pokok bahasan ciri-ciri virus, maka hasil penelitian dapat disimpulkan bahwa :

1. Penerapan pembelajaran model ARIAS (Assurance, Relevance, Interest, Assessment, dan Satisfaction) dapat meningkatkan keaktifan siswa kelas X IPA ${ }_{1}$ SMA Iqra' Terpadu Kota Bengkulu dalam proses belajar mengajar pada pokok bahasan ciri-ciri virus. Peningkatan ini dapat dilihat dari kenaikan skor keaktivan siswa pada setiap siklus, yakni pada siklus I skor ratarata 34,5 dengan kategori baik, kemudian pada siklus II dan siklus III skor rata-ratanya samasama 41 dengan kategori baik.

2. Penerapan model pembelajaran ARIAS (Assurance, Relevance, Interest, Assessment, dan Satisfaction) dapat meningkatkan hasil

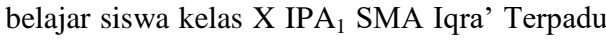
Kota Bengkulu pada pokok bahasan ciri-ciri virus.Peningkatan hasil belajar ini dilihat dari setiap siklusnya. Pada siklus I nilai rata-rata siswa 7,0 dengan ketuntasan belajar secara klasikal 56,25 \%, siklus II nilai rata-rata siswa mengalami peningkatan yaitu 76,25 dengan ketuntasan belajar secara klasikal 78,12\% dan siklus III nilai rata-rata siswanya meningkat menjadi 79,21 dan ketuntasan belajar secara klasikalnya adalah menjadi $87,5 \%$.

\section{DAFTAR PUSTAKA}

Arikunto, S. 2002. Dasar-Dasar Evaluasi Pendidikan. Jakarta: Bumi Aksara.
Arikunto, S. 2002. Prosedur Penelitian Suatu Pendekatan Praktek. Yogyakarta: Rineka Cipta.

Depdiknas. 2006. Kurikulum Tingkat Satuan Pendidikan (KTSP) Standar Kompetensi Mata Pelajaran Ilmu Pengetahuan Alam. Bengkulu: Depdiknas.

Djamarah, S. B dan Aswan, Z. 2006. Strategi Belajar Mengajar. Bandung: Sinar Baru.

Hamalik, O. 1992. Psikologi Belajar dan Mengajar. Bandung: Sinar Baru.

Hamalik, O. 2001. Kurikulum dan Pembelajaran. Jakarta: Bumi Aksara.

Haryati, Daroji. 2007. Konsep dan Penerapan SAINS BIOLOGI 1 Untuk Kelas VII SMP dan MTs. Solo: PT. Tiga Serangkai.

Nasution. 1995. Didaktik Asas-Asas Mengajar. Bandung: Rineka Cipta.

Purwanto, N. 2004. Prinsip-Prinsip dan Teknik Evaluasi Pengajaran. Jakarta: Remaja Rosdakarya.

Rostieyah. 2001. Strategi Belajar Mengajar. Jakarta: Renika Cipta.

Rani, S. 2006. Upaya Meningkatkan Hasil Belajar Siswa Pada Konsep Energi dan Usaha Di Kelas VIIb SMP N 11 Bengkulu Dengan Model Pembelajaran ARIAS Melalui Metode Eksperimen. Skripsi: UNIB. Tidak dipublikasikan.

Slameto. 2003. Belajar dan Faktor-Faktor yang Mempengaruhi. Jakarta: Rineke Cipta.

Sopah, Djamaah. 2007. Pengembangan dan Penggunaan Model Pembelajaran ARIAS.http://www.Ncela.guru.edu/practic e/itclessons/model Pembelajaran ARIAS. Htm.

Sudjana, N. 2001. Penilaian Hasil Proses Hasil Belajar Mengajar. Bandumg: PT Remaja Rosdakarya.

Sudjoko, S. M. 1985. Pengajaran Biologi Secara Individual. Jakarta: Universitas Indonesia.

Soetomo. 1993. Dasar-Dasar Interaksi Belajar Mengajar. Usaha Nasional: SurabayaIndonesia. 
VOL. 1 NO. 2, SEPTEMBER 2020 JURNAL BIOEDUSCIENTIFIC PPs UNMUH BENGKULU e-ISSN: 2721-5881

Sekolah Menengah Pertama (SMP) Negeri 11. 2008.

Kriteria Ketuntasan Minimal

(KKM). Pemerintah Kota Bengkulu Dinas

Pendidikan Nasional:

Bengkulu.

Wardani, dkk. 2005. Penelitian Tindakan Kelas. Jakarta: Universitas Terbuka.

Wiherington, dkk. 1986. Teknik-Teknik Belajar dan Mengajar. Bandung: Jemmars.

Zuriah, N S. 2007. Metodologi Penelitian Sosial dan Pendidikan Teori Aplikasi. Malang: Bumi Aksara. 